\title{
The China-Australia Free Trade Agreement (ChAFTA): Its Implications for Australia-United States Relations
}

\author{
Johni R. V. Korwa ${ }^{1}$ \\ ${ }^{1}$ Faculty of Social and Political Sciences, Cenderawasih University, Indonesia, \\ korwajohni@yahoo.com
}

\begin{abstract}
Australia is currently faced with a strategic and economic dilemma regarding its interactions with China and the United States (US). On the one hand, it should maintain and strengthen its strategic relations with the US as an ally in order to contain a rising China. On the other hand, Australia should ensure its economic growth by strengthening trade relations with China. This paper aims to examine the implications of the new China-Australia Free Trade Agreement (ChAFTA) for the Australia-US alliance (ANZUS). Through qualitative approach, this article analyzes the issues with the use of realist perspective in international relations. By assessing two previous events involving the triangular Australia-US-China relationship (the case of the Taiwan conflict and the US development of a National Missile Defense system), this paper summaries three findings: a fundamental shift in the way Australia perceives China; ChAFTA offers more benefits to Australia than the Australia-US Free Trade Agreement (AUSFTA); and finally, the US is irreplaceable in Australia's national security despite the benefits of trade with China.
\end{abstract}

Keywords: Australia; China; ChAFTA; ANZUS

\section{ABSTRAK}

Australia saat ini dihadapkan dengan dilema strategis dan ekonomi mengenai interaksinya dengan China dan Amerika Serikat (AS). Di satu sisi, ia harus mempertahankan dan memperkuat hubungan strategisnya dengan AS sebagai sekutu untuk membendung kebangkitan Cina. Di sisi lain, Australia harus memastikan pertumbuhan ekonomi dengan memperkuat hubungan perdagangannya dengan China. Tulisan ini bertujuan untuk melihat implikasi dari Perjanjian Perdagangan Bebas China-Australia (ChAFTA) terhadap aliansi Australia-AS (ANZUS). Melalui pendekatan kualitatif, artikel ini menganalisa topik tersebut dengan menggunakan pandangan realis dalam hubungan internasional. Dengan mereview dua peristiwa sebelumnya yang melibatkan hubungan segitiga Australia-AS-Cina (kasus konflik Taiwan, dan pengembangan sistem Pertahanan Rudal Nasional AS), tulisan ini merangkum tiga argumen: perubahan mendasar dalam cara Australia memandang Cina; ChAFTA menawarkan lebih banyak manfaat bagi Australia daripada Perjanjian Perdagangan Bebas Australia-AS (AUSFTA); dan Amerika Serikat tidak akan tergantikan dalam kepentingan keamanan nasional Australia meskipun keuntungan perdagangan dengan Cina.

Kata kunci: Australia; Cina; ChAFTA; ANZUS

\section{Introduction}

In the field of international relations, commercial liberals believe that economic cooperation can forestall or reduce the likelihood of conflict. The purpose of trade amongst countries is essentially to share economic benefits between each other, as well as to build strong relationships. A great deal of trade nowadays is set up by the World Trade Organization (WTO) which facilitates not only 
42 Johni R. V. Korwa | The China-Australia Free Trade Agreement (ChAFTA): Its Implications for Australia-United States Relations

bilateral but also multilateral Free Trade Agreements (FTAs). ${ }^{1}$ One example of a bilateral FTA is the China Australia Free Trade Agreement (ChAFTA). After signing the Trade and Economic Framework in 2003, both Australia and the People's Republic of China made further bilateral commitments to enter into a new phase of FTA negotiation. ${ }^{2}$ Clearly, this represented a further strengthening of economic relations between Australia and China. Yet, some argue that China is actually using its trade cooperation to seek power in the Asia Pacific. ${ }^{3}$ To be more precise, China is using trade as the means to build a soft hegemony in the Asia Pacific in order to become a superpower. Unfortunately, many are very concerned that China may then adapt America's model of the Monroe Doctrine to assert its regional rise, thereby challenging US' power in the Asia Pacific. ${ }^{4}$ Others maintain that China is using its economic influence to search for great power potential to weaken the US regional primacy in Asia Pacific, and Australia has become entangled in that tactic. ${ }^{5}$

In November 2011 the former US President Barrack Obama announced his new approach to East Asia in the Australian

${ }^{1}$ L. L. He \& R. Sappideen. Free trade agreements and the US-China-Australia relationship in the AsiaPacific region. Asia Pacific Law Review 21, 1, pp.55. 2013.

${ }^{2}$ M. Vaile, MP (former minister for trade). AustraliaChina Trade and Economic Framework (2003, October 24). Retrieved from http://trademinister.gov.au/releases/2003/mvt085_03. html

${ }^{3}$ T. Lum, W. M. Morrison, and B. Vaughn, China's "Soft Power" in Southeast Asia. CRS report for Congress, pp. 1. 2008.

${ }^{4}$ H. White, Power Shift: rethinking Australia's place in the Asian Century. Australian Journal of International Affairs 65, 1, pp. 84

${ }^{5}$ D. Blumenthal, Strengthening the US-Australia Alliance: Progress and Pitfalls. American Enterprise Institute for Public Policy Research 29, pp. 5. 2005.
Parliament called "The Pivot". ${ }^{6}$ Obama emphasized that The Pivot or strategic rebalance toward Asia could be achieved in a number of ways, one of which is the strengthening of bilateral security ties with the US allies in Asia, including Australia. ${ }^{7}$ Strengthening bilateral security ties included the US military bases involvement in the regional multilateral institutions, and the extension of trade and investment links such as the proposed Trans Pacific Partnership (TPP $)^{8}$, which is unfortunately opposed by the current President of the US Donald Trump. ${ }^{9}$ This paper argues that the China-Australia Free Trade Agreement may make their relationship stronger in terms of economic factors, but Australia would not risk its national security in the expense of ChAFTA. This paper will first examine the ChAFTA in comparison with AUSFTA, and then assess its implications for the Australia-US alliance (ANZUS). ${ }^{10}$ Two previous regional events (related to Taiwan and the US National Missile Defense (NMD)) will be scrutinized to illustrate the changing nature of the triangular relationship. The issues will be analyzed using realist perspective in international relations.

\footnotetext{
${ }^{6}$ B. He, Collaborative and Conflictive Trilateralism: Perspectives from Australia, China, and America. Asian Survey 54, 2, pp. 267. 2014.

${ }^{7}$ Ibid, pp. 268

${ }^{8}$ Ibid.

${ }^{9}$ E. White, Financial Times, (2018, April 18). Trump says he is now opposed to re-joining TPP, Retrieved from https://www.ft.com/content/ed6b16f4-42b511e8-803a-295c97e6fd0b

${ }^{10}$ ANZUS (Australia, New Zealand, and United States) is a strategic alliance established on 1 September 1951. This alliance is created as a result of the aftermath of the war in the Pacific. This is neither a regional pact in comparison with the North Atlantic Organization (NATO), nor a bilateral treaty which seek for assistance, economic or military. See Joint Committee on Foreign Affairs and Defense, The ANZUS Alliance (pp. 1). Canberra: Australian Government Publishing Service. 1982.
} 
43 Johni R. V. Korwa | The China-Australia Free Trade Agreement (ChAFTA): Its Implications for Australia-United States Relations

\section{Background: The China-Australia Free Trade Agreement (ChAFTA) compared to Australia- US Free Trade Agreement (AUSFTA)}

The notion of ChAFTA first emerged in the Australia-China Trade and Economic Framework agreement signed in Canberra on 24 October 2003 by Mark Vaile as a representative of Prime Minister John Howard and $\mathrm{Yu}$ Guangzhou as representative of President $\mathrm{Hu}$ Jintao. ${ }^{11}$ The framework stated that the government of Australia and the People's Republic of China agreed to conduct a detailed joint feasibility study into the benefits of a FTA. The subsequent Joint Feasibility Study completed in March 2005. ${ }^{12}$ A collaboration between the Centre of Policy Studies of Monash University and the Chinese Academy of Social Sciences and Nankai University using economic modeling the study concluded that a ChAFTA could provide significant output and job opportunities for both China and Australia. The Australian Department of Foreign Affairs (DFAT) noted that:

If (ACFTA) had commenced from 2006, 'Australia's real GDP would receive a US\$18 billion (A $\$ 24.4$ billion) boost in present value terms over the period 2006 15, and China's real GDP would increase by up to US\$64 billion (A $\$ 86.9$ billion) over the same period. ${ }^{13}$

On completion of the Joint Feasibility Study, Prime Minister John Howard went to China in April 2005 and entered into FTA negotiations with Premier Wen Jiabao. ${ }^{14}$ In November 2014, following long negotiations, a

${ }^{11}$ A. Clarke \& X. Gao, Bilateral Free Trade

Agreements: A comparative analysis of the AustraliaUnited States FTA and the forthcoming Australia-

China FTA. UNSW Law Journal 30, 3, pp. 846. 2007.

${ }^{12}$ Ibid

13 Ibid, pp. 847

${ }^{14}$ Ibid
Declaration of Intent was signed by the Australian Trade and Investment Minister Andrew Robb and the Chinese Commerce Minister Gao Hucheng. It stated that the new ChAFTA had formally entered into force. ${ }^{15}$

By implementing ChAFTA, both countries expect to increase trade and share the benefits. According to data from DFAT, almost all of Australia's resources, energy and manufacturing exports would enter China dutyfree within four years of the agreement (2019). ${ }^{16}$ ChAFTA is expected to enhance the competiveness of Australian agricultural exports to China, eliminating tariffs on meat, dairy and wine. It is believed Australian consumers and businesses will have access to cheaper and a more diverse range of Chinese goods and services. ${ }^{17}$ ChAFTA will deliver Australian services providers a significant leg-up in the Chinese economy. ChAFTA will also promote Chinese investment in Australia, fuelling future economic growth by lifting the screening threshold for private Chinese investments in non-sensitive sectors. ${ }^{18}$ Specifically, ChAFTA set China's tariffs at zero over 85 per cent (by 2015 value) of Australian exports would enter China duty free or at preferential tariff rates by the time it came into force. This amount would increase to 93 per cent coverage by 1 January 2019 and 98 per cent when ChAFTA is fully implemented. Australian import tariffs has been set by ChAFTA at zero on 82 per cent of China's exports to Australia from day one,

15 Australian Embassy (China), (2014, November 17). Statement at announcement of conclusion of FTA negotiations. Retrieved from http://china.embassy.gov.au/bjng/HOMstatement.htm 1

${ }^{16}$ Department of Foreign Affairs and Trade. ChinaAustralia Free Trade Agreement. Retrieved from http://dfat.gov.au/trade/agreements/inforce/chafta/fact-sheets/Pages/fact-sheet-resourcesenergy-and-manufacturing.aspx

${ }^{17}$ Ibid

${ }^{18}$ Ibid 
44 Johni R. V. Korwa | The China-Australia Free Trade Agreement (ChAFTA): Its Implications for Australia-United States Relations

rising to 100 per cent tariff elimination by 1 January $2019 .{ }^{19}$

In comparison, many observers believe that the Australia-US Free Trade Agreement (AUSFTA) offers fewer benefits to Australia. For example, the AUSFTA failed to cover all sectors, excluding sugar, and forestalling the removal of tariffs on Australian beef and dairy. ${ }^{20}$ The exclusion of sugar has been discussed by Australian farmers as well as some American commentators, maintaining that it is inconsistent with Bush's statements regarding the opening of all sectors under AUSFTA. DFAT stated that:

Sugar was a sensitive issue for the United States ... and it did not prove possible for the United States to offer to increase current access. Faced with a decision of whether to walk away from the negotiations, the Government decided that the potential benefits from AUSFTA as a whole did not justify denying those benefits to the rest of the Australian community for the sake of one - albeit very importantagricultural sub-sector. ${ }^{21}$

In short, it can be argued that AUSFTA was in some respects disappointing for Australia. As a consequence, it may have produced a shift in the way Australia perceives its relations with the US. Indeed, as observed by Kelton, there was a structural fragility in Australia's efforts to respond to shifts in the international system, in particular to the formulation of policy choices towards the US in terms of the delivery of trade outcomes

\footnotetext{
${ }^{19}$ Department of Foreign Affairs and Trade. Guiding to using ChAFTA to export or import. Retrieved from https://dfat.gov.au/trade/agreements/inforce/chafta/doing-business-with-china/Pages/guideto-using-chafta-to-export-or-import.aspx

${ }^{20}$ Clarke and Gao, op.cit., pp. 844

${ }^{21}$ Ibid, pp. 845
}

concerning AUSFTA. ${ }^{22}$ Moreover, Armstrong found that there was not only a reduction in trade between the US and Australia but also in their exports and imports. The coefficient estimate (in proportional change terms) for trade between the United States and Australia due to AUSFTA is $-0.304 .{ }^{23} \mathrm{He}$ also maintained that trade diversion had occurred as a result of AUSFTA due to the collapse of US trade in 2008 and global finance crisis. Interestingly, he observed that the trade diversion between Australia-US may have fallen without the implementation of AUSFTA. ${ }^{24}$

Regarding ChAFTA, this agreement is expected to offer greater benefits to Australia despite the fact that it failed to deal with sugar in AUSFTA (failed also to deal with tariffs for cotton, rice, and wheat). ${ }^{25}$ Even so, ChAFTA covers other important sectors which were not covered in AUSFTA such as dairy products, beef, mining and wine. Tariffs on these products will be scrapped as well China's tariffs on Australian resources and energy products. $^{26}$ Indeed, for Australian Prime Minister Tony Abbott, ChAFTA is good for the Australian economy:

"In particular it is a very good day for Australia. And this agreement is the first that China has concluded with a

\footnotetext{
${ }^{22}$ M. Kelton, More than an Ally? Contemporary Australia-US Relations (pp.1). Ashgate Publishing Limited (England) \& Ashgate Publishing Company (USA). 2008.

${ }^{23} \mathrm{~S}$. Armstrong, The economic impact of the Australia-US Free Trade Agreement' AJRC working paper 01/2015 (pp. 10). Australian: ANU AustraliaJapan Research Center. 2015.

${ }^{24}$ Ibid

${ }^{25}$ L. Barbour, (2014, 18 November). Free trade agreement Dairy farmers set to big winners in deal between Australia and China (para. 3). Retrieved from http://www.abc.net.au/news/2014-1116/australia-looks-set-to-sign-a-free-trade-agreementwith-china/5895012.

${ }^{26}$ Ibid, para. 4-5
} 
45 Johni R. V. Korwa | The China-Australia Free Trade Agreement (ChAFTA): Its Implications for Australia-United States Relations

substantial economy, with a major economy and it is the most comprehensive agreement that China has concluded with anyone. ${ }^{27}$

A glance at Australia's trade and investment with China in 2013-14 provides some insight into the benefits of ChAFTA for Australia. Australia's top five exports such as iron ore and concentrates $(\$ A 57.0 \mathrm{~b})$, coal (\$9.3b), gold (\$8.1b), education-related services $(\$ 4.1 \mathrm{~b})$, and copper $(\$ 2.1 \mathrm{~b})$ are delivered to China. ${ }^{28}$ Australia's top five imports from China include clothing $(\$ 5.1 \mathrm{~b})$, telecommunications equipment and parts $(\$ 4.9 \mathrm{~b})$, computers $(\$ 4.8 \mathrm{~b})$, furniture, mattresses, and cushions $(\$ 2.2 b)$, and prams, toys, games and sporting goods $(\$ 1.8 \mathrm{~b}){ }^{29}$ China has become Australia's biggest trading partner ensuring around $\$ 160$ billion in trade during 2013-14, accounting for $25 \%$ of Australia's total trade. Australia's investment relationship with China is also increased considerably, starting from only $\$ 1$ billion in 2003 to around $\$ 32$ billion in 2013, thus making China Australia's eighth-largest source of investment. ${ }^{30}$

Looking in more detail at triangular trade in 2013, China was by far Australia's largest export destination in terms of goods and services, accounting for around $10.3 \%$ share of the total Australia's global export, while the US stood in the second place (at $9.6 \%$ share). ${ }^{31}$ In

27 Ibid, para. 10-11

${ }^{28}$ Department of Foreign Affairs and Trade, ChAFTA snapshot infographic.

Retrieved from

http://dfat.gov.au/trade/agreements/in-

force/chafta/fact-sheets/Pages/chafta-snapshot-

infographic.aspx

${ }^{29}$ Ibid

${ }^{30}$ Ibid

${ }^{31}$ Department of Foreign Affairs and Trade, Australia's Trade and Economic Statistics. Retrieved from http://dfat.gov.au/about-us/publications/tradeinvestment/trade-at-a-glance/trade-at-a-glance- contrast, the US dominated about $11.9 \%$ share of Australia's global imports in terms of goods and services, followed by China (9.8\% share). ${ }^{32}$ With regard to the two-trading partners, on the other hand, China still remained the most important country for Australia accounting for a $23.3 \%$ share of total goods and services, followed by Japan (10.9\% share) and the US (8.4\% share). ${ }^{33}$ In a nutshell, it is clear that China is a more important partner for Australia in terms of trade.

\section{The impact of ChAFTA on the Australia-US alliance (ANZUS)}

In order to assess the impact of ChAFTA on the future of the strategic AustraliaUS alliance (ANZUS), two previous events regarding the triangular relationship will be examined; first, the case of China-US tensions over Taiwan, and second, the case of US development of a National Missile Defense system (NMD). During the 1996 Sino-American confrontation over Taiwan and China again claimed Taiwan as part of its territory and reiterated the need for reunification in which Beijing reasserted 'One China policy'. The US, which had supported Taiwan for some time in order to contain communism, intervened and asserted that reunification by force was forbidden. ${ }^{34}$ This standoff pressured Canberra, a US ally in the Asia Pacific to take a position. Initially, Australia's Foreign Minister, Alexander Downer, urged China's Ambassador to exercise restraint. ${ }^{35}$ Downer even tacitly referred to the placement of two US aircraft

2014/Pages/performance-03-australias-trade-andeconomic-statistics.aspx

32 Ibid

${ }^{33}$ Ibid

${ }^{34}$ K. Lieberthal, Preventing a war over Taiwan. Foreign Affairs 84, 2, pp. 2. 2005.

${ }^{35} \mathrm{~W}$. Tom and L. Hay, Australia, the United States and a 'China growing strong': managing conflict avoidance. Australian Journal of International Affairs 55, 1, pp. 40. 2001. 
carriers east of Taiwan. Consequently, SinoAustralian relations cooled over the following months. ${ }^{36}$

However, the Howard government subsequently changed its tune. In late 1996, the Chief of the Australian Defense Force (ADF), General John Baker, visited China in order to rebuild the relationship. ${ }^{37}$ In the following year, Australia and China committed themselves to annual discussions on regional security, and opened certain avenues for their military officers to study at each other's strategic institutes. ${ }^{38}$ In order to further strengthen Australia's relations with China, Prime Minister John Howard visited China in 1997 and clearly explained that Australia's relations with China would be considered in Australia's national interests. He also emphasized the importance of the 'One China policy' in which Australia and the US acknowledged Taiwan as an integral part of China, emphasizing that Taiwan should not be incorporated by the use of force. ${ }^{39}$

The gradual restoration of SinoAustralia relations placed Australia in a dilemma with regards to the strategic alliance with the US, a dilemma illustrated by the so-called 'Armitage Scenario'. In 1999, Richard Armitage, a former US Assistant Secretary of Defense visited Australia and made strong statements about Australian military support for the US in the event of a Sino-Taiwanese conflict. Further, it was suggested, if Australia failed to provide such support, then the ANZUS treaty would need to be re-evaluated. ${ }^{40}$ These statements seem to bring into question the security guarantee the ANZUS alliance implicitly provided Australia. If the conflict over Taiwan was to be repeated and Australia did not

\footnotetext{
${ }^{36}$ Ibid

${ }^{37}$ Ibid, pp. 41

${ }^{38}$ Ibid

39 Ibid

${ }^{40}$ Ibid, pp. 42
}

join the US in that conflict, it may have repercussions for the Alliance.

In response to the 'Armitage Scenario', President Jiang Zimen firmly warned Australia about the "very serious consequences' of intervening in a US-Taiwan conflict. President Zimen again responded to Armitage's statements when he visited Australia the following week. ${ }^{41}$ During the visit Prime Minister Howard stated that Australia's position would be to remain neutral in the case of a US-China conflict over Taiwan. Thus, despite pressure from the US, Australia stood firm, announcing a two-pronged policy approach emphasizing Australia's neutral position. ${ }^{42}$ Subsequently, Australia and China advanced their bilateral trade relations, signing several agreements facilitating the export of Australian minerals, and the negotiations for the export of Australian liquid natural gas (LNG) to China. ${ }^{43}$

In the case of the US National Missile Defense system (NMD), here Australia was pressured by the US to work closely on the development of a "high technology defense force". Indeed, Harvard University strategic analyst Robert D. Blackwill, a specialist in US alliance relations in Asia, pressured Australia to become actively involved in the American-led NMD. ${ }^{44}$ Interestingly, even though Australia had previously participated in missiles research and development, on this occasion it refused to play a significant role in the development of the NMD. In September 1997, for instance, Australia would not fully engage with the US in the project DUNDEE (Down Under Early Warning Experiments) which included the involvement of Australia's JINDALEE over-thehorizon radar which enabled to monitor air and

\footnotetext{
${ }^{41}$ Ibid

${ }^{42}$ Ibid

${ }^{43}$ Ibid, pp. 42-43

${ }^{44}$ Ibid, pp. 43
} 
47 Johni R. V. Korwa | The China-Australia Free Trade Agreement (ChAFTA): Its Implications for Australia-United States Relations

sea movements and launching ballistic missiles in the Asia Pacific. ${ }^{45}$

Furthermore, Australian decision makers also made clear Australia's unwillingness to participate in the development of the NMD. As stated by Defense Minister Ian McLachlan in August 1997, "it is prudent that we [Australia] acquire an understanding of ballistic missile defense technology' but that Australia has no intention of developing an indigenous system of its own." ${ }^{46}$ Clearly, even though Australia desires to work closely with the US to develop missile defense technology, it will not do this by itself. Having said that, Australia still played an indirect role in ensuring various types of missile defense operations with the US such as facilitating the possible deployment of a Theatre Missile Defense (TMD) network in order to counter China's missile development aimed at Taiwan. ${ }^{47}$

In this context, China had made some efforts to weaken Australia's collaboration with the US. This can be seen in Chinese press commentaries condemning US regional allies for possible participation in the NMD. ${ }^{48}$ By strengthening trade relations with Australia through ChAFTA, Beijing believed it might be able to reduce Australia's involvement in NMD, and thereby also weaken the ANZUS alliance. Beijing also endeavored to push Australia away from ANZUS by proposing Australia become a predominantly region-centric power, one concerned with security measures in the Asia Pacific, such as acting as a peacekeeping forces East Timor, and encouraging Australia to join the biannual Asia-Europe Meetings (ASEM). ${ }^{49}$

Two cases seem to illustrate that Australia's position is not as consistent or predictable as might be expected with regard to

\footnotetext{
${ }^{45}$ Ibid, pp. 44

${ }^{46}$ Ibid

${ }^{47}$ Ibid

${ }^{48}$ Ibid, pp. 45

49 Ibid
}

its principle partners. Australia's neutral position regarding Taiwan, and its ambivalence toward the NMD, seem to indicate a desire to avoid harming its trade relations with China. ${ }^{50}$ Regarding the ANZUS treaty, this offers a number of benefits to Australia including national security, access to US intelligence networks, and access to US military training. ${ }^{51}$ Yet the Treaty may not necessarily guarantee Australia's security in the future if China successfully transfers its economic power into military power, thereby challenging the US. This is perhaps due to vague commitments in the Treaty, particularly article IV which states:

"Each Party recognizes that an armed attack in the Pacific Area on any of the Parties would be dangerous to its own peace and safety and declares that it would act to meet the common danger in accordance with its constitutional processes. ${ }^{52}$

This article is quite different to the equivalent NATO Article 5 which states:

"The Parties agree that an armed attack against one or more of them in Europe or North America shall be considered an attack against them all and.... including the use of armed force, to restore and maintain the security of the North Atlantic area" 53

\footnotetext{
${ }^{50}$ G. Brown and L. Rayner, (2001, August 28). Upside, Downside: ANZUS: After 50 years. Retrieved from http://www.aph.gov.au/About_Parliament/Parliament ary_Departments/Parliamentary_Library/Publications Archive/CIB/cib0102/02CIB03

${ }^{51}$ N. Bisley, An ally for all the years to come: why Australia is not a conflicted US ally. Australian Journal of International Affairs 67, 4, pp. 405. 2013.

52 Report from the Joint Committee on Foreign Affairs and Defense, the ANZUS Alliance, Australian Government Publishing Service (Annex A - Security Treaty between Australia, New Zealand, and the United States of America), Canberra. 1982. ${ }^{53}$ The North Atlantic Treaty. 1949.

Retrieved from. http://www.nato.int/nato_static/assets/pdf/stock_publ ications/20120822_nato_treaty_en_light_2009.pdf
} 
48 Johni R. V. Korwa | The China-Australia Free Trade Agreement (ChAFTA): Its Implications for Australia-United States Relations

Despite the vague wording of the ANZUS treaty, Australia's connection with the US is on the most important interest for Australian defence policy. As mentioned in the 2016 Defence White Paper that "the US will continue to be Australia's most important strategic partner through our long-standing alliance..." While it is true that China is now playing an important trade partner with Australia (ChAFTA), Canberra would never ever replace the US in the Australian national security concerns. Even though economic cooperation remains important, states always refer back to national security as the number one concern.

\section{Analysis: Realist perspective on ChAFTA and its implications for the Alliance}

Realists argue that the international system is characterized by anarchy, and that competition between countries is inevitable. National security and international order is secured through shifting balances of power in a system of 'self-help'. By accruing power, a state will ensure its existence in the international system. ${ }^{55}$ Currently, China seems to be seeking power through the development of anapproach which includes the use of FTAs and perhaps ChAFTA. Hugh White observes that China may replace the US over the next 30 years as the largest economy in the world, particularly if China's economy grows as it did in the last 30 years. ${ }^{56}$ Likewise, John Maersheimer maintains that China, which has a huge population in comparison with the US, has significantly developed its economy since the early 1980s. If

\footnotetext{
54 The 2016 Defence White Paper, www.defence.gov.au/whitepaper/docs/2016-defencewhite-paper.pdf

55 J. Grieco, G. J. Ikenberry, and M. Mastanduno, Introduction to International Relations: enduring questions and contemporary perspectives (pp. 72). Palgrave: Great Britain. 2015.

56 White, Power shift: rethinking Australia's place in the Asian century, op. cit., p. 82.
}

China, Maersheimer emphasizes, continues to increase its economic power in the years to come, this may be transferred into material military power and thus challenge the military primacy of the US in East Asia. ${ }^{57}$

Realists are interested in how peace and order can be secured through the formation of alliances, particularly in order to counterbalance the rise of a new powerful state. ${ }^{58}$ In the case of the rise of China, it is clear that the US is very concerned, prompting the shift in focus from the Middle East to Asia, as marked by the withdrawal of troops from Iraq and Afghanistan. ${ }^{59}$ Apart from this, the US also endeavors to contain China's rise by strengthening strategic alliances such as ANZUS. This can be seen in the AustralianUnited States Ministerial Meeting (AUSMIN) in 2015 and 2018, where the respective leaders committed to strengthening ANZUS and trade relations in order to contain the re-emergence of China. ${ }^{60}$

With regards to the signing of ChAFTA, this has assisted the economic and strategic reemergence of China through trade. This is seemingly acknowledged in Australia's defense white papers. The 2013 and 2017 Defense White Paper is totally contrary to the previous Defense White Paper of 2009 which underscored China as a threat. In contrast both paper declared that

57 J. J. Maersheimer, 'Structural Realism', in T. Dunne, M. Kurki and S. Smith (2nd edition), International Relations Theories: Discipline and Diversity (pp. 89), United States of America: Oxford University Press. 2010.

${ }^{58}$ Grieco, Ikenberry, and Mastanduno, op.cit, pp. 74

${ }^{59}$ H. Clinton, America's Pacific Century. Foreign Policy 189, pp. 57. 2011.

${ }^{60}$ U.S. Department of State, '2015 Australia-United States Ministerial (AUSMIN) Joint Statement', Retrieved from https://2009-

2017.state.gov/r/pa/prs/ps/2015/10/248170.htm. See also Department of Foreign Affairs and Trade, 'Joint Statement Australia-U.S. Ministerial Consultations ("AUSMIN")" 2018. Retrieved from https://foreignminister.gov.au/releases/Pages/2018/jb _mr_180724a.aspx 
49 Johni R. V. Korwa | The China-Australia Free Trade Agreement (ChAFTA): Its Implications for Australia-United States Relations

Australia "Welcomes China's rise" and acknowledged the development of China's economy as a cornerstone to increase its military power naturally. ${ }^{61}$ Prime Minister John Howard acknowledged that China's economic growth was linked to Australia's prosperity and trade relations with China. ${ }^{62}$ Even though there are regular AUSMIN meetings between Australia and the US, it must be said that Australia now perceives China differently.

The US, in these circumstances, is expected to admit the re-emergence of China as a natural process in the international system. As observed by Lee, there were not any countries that increased military capability as well as economic sector outside of the US-led Western alliance system and rising as a great power since the post War-World Two; yet China did. ${ }^{63}$ China, one of five permanent members of the UN Security Council, should be acknowledged as a great power because no one can argue that Beijing is now expanding its influence to pursue hegemony in the Asia Pacific through FTAs with Australia, New Zealand and ASEAN. Indeed, John Maersheimer, in examining great powers in action, found that regional hegemony would be always sought by powerful states to increase their power as well as to ensure their survival in the international system. ${ }^{64}$

Avery Goldstein observes that, in the post-Cold War era of the early of twenty first century, China's leaders have endeavored to not

\footnotetext{
${ }^{61}$ J. Lee, Australia's 2015 Defense White Paper; Seeking Strategic Opportunity in Southeast Asia to Help Manage China's Peaceful Rise. Contemporary Southeast Asia 35, 3, p. 400. 2013. See also The 2017 Foreign Policy White Paper (Australian

Government), Retrieved from https://www.fpwhitepaper.gov.au/file/2651/download ?token=Q5CYuX29

${ }^{62}$ White, 'Power shift: rethinking Australia's place in the Asian century,' op. cit, pp. 82

${ }^{63}$ Lee, op.cit., pp. 401

${ }^{64}$ J. J. Mearsheimer, The Tragedy of Great Power Politics (p. 168). USA: W. Norton and Company. 2001.
}

only to deal with shifts in the nature of the international system, but also to ensure the reemergence of their country as a great power. These efforts produced a new grand strategy in China's foreign policy in the late 1990s. ${ }^{65}$ Beijing believed that the bipolarity of the ColdWar was replaced by a new era of unipolarity which in turn opens certain avenues to multipolarity. China perceived this multipolarity as an opportunity for its peaceful re-emergence in the international system. ${ }^{66}$ Yet, others maintain that China is essentially seeking greater status in the international system or, to a lesser extent, they argue that China seeks to challenge the hegemony of the US. ${ }^{67}$

Canberra is very concerned to retain the US as a strategic ally, but it is also committed to ensuring its good economic relationship with China through ChAFTA. As argued by Rosecrance, while it is true that Australia may cooperate with the US to contain the reemergence of China, this does not mean Australia has to put its relations with China in danger. ${ }^{68}$ Indeed, as Shannon Tow observes, there is a view amongst international relations scholars that 'junior allies' might have a choice whether or not to underpin their senior allies, or change position in response to the rise of a challenger. ${ }^{69}$ Prime Minister Kevin Rudd also maintained that Australia should consider the way it treats China and the US or, to be more precise, while Australian should consider China an "important partner", the US should be

\footnotetext{
${ }^{65}$ A. Goldstein, 'An emerging China's emerging grand strategy', in G. J. Ikenberry \& M. Mastanduno (ed), International Relations Theory and the AsiaPacific (pp. 57) New York: Columbia University Press, New York. 1893.

66 Ibid

${ }^{67}$ Ibid, pp. 59

${ }^{68} \mathrm{He}$, op.cit, pp. 258

${ }^{69} \mathrm{~S}$. R. Tow, Diplomacy in an asymmetric alliance: reconciling Sino-Australian relations with ANZUS, 1971-2007. International Relations of the AsiaPacific 12, 1, pp. 72. 2011.
} 
regarded as a "strategically important partner". ${ }^{70}$ It seems that the way Australia perceives the US as part of ANZUS look differently.

\section{Conclusion: ChAFTA and the Alliance}

The signing of the China-Australia Free Trade Agreement (ChAFTA) marks a significant milestone in the bilateral relationship, and represents an instrument for strengthening the relationship for the years to come. No one can argue that Australia's economic growth is tied to China's economic growth through mineral exports in particular. The US may view this strengthening relationship differently. Whilst the US appears to be trying to strategically contain the re-emergence of China, Australia is simultaneously entering into a new trade relationship with China. As demonstrated by previous 'strategic' pressures from the US, in particular the Taiwan and NMD episodes, Australia appears to be increasingly determined not to jeopardize its economic relations with China. Nevertheless, Australia still considers the US as the strategic partner which cannot be replaced in terms of the national security. In addition, by using realist perspective to approach the triangular Australia-US-China relationship, the rise of China and the implication of ChAFTA for Australia-US relations can be clearly analyzed.

In short, there are at least three assumptions outlined in this paper. First, there is a fundamental shift in the way Australia now perceives China. Australia is now strongly economically integrated into the Asia Pacific economic region, particularly Chinese economic development. Australia has come to understand that integrating itself into the Asia Pacific region will ensure its future both economically and politically. ${ }^{71}$ Second, Australia may consider that ChAFTA is more economically beneficial in comparison with the AUSFTA. As discussed,

\footnotetext{
${ }^{70}$ He, op.cit, pp. 258

71 Tow and Hay, op.cit. pp. 38
}

even though AUSFTA has been in place since early $2004,{ }^{72}$ it does not seem to have provided the economic benefits Australia had hoped. In fact, there is a reduction in trade between the US and Australia under AUSFTA, as well as trade dispersion. Third, despite the fact that ChAFTA brings economic benefit greatly to Australia, Australia would not risk its national security in the expense of ChAFTA. An Australia-US relation is paternalistic. This means that the US is irreplaceable in Australia's national interest, whereas China remains a great threat for Australia's security. Trade is highly important for Australia, but states security always come first.

\section{REFERENCES}

Armstrong, S., 'The economic impact of the Australia-US Free Trade Agreement' AJRC working paper 01/2015. ANU Australia-Japan research center.

Australian Embassy (China), 'Statement at announcement of conclusion of FTA negotiations', 17 November 2014.

Retrieved from http://china.embassy.gov.au/bjng/HOMst atement.html [Accessed 30 June 2018]

Barbour, L., 'Free trade agreement: Dairy farmers set to be big winners in deal between Australia and China', News (website) 18 November 2014, para. 3. Retrieved from http://www.abc.net.au/news/2014-1116/australia-looks-set-to-sign-a-freetrade-agreement-with-china/5895012 [Accessed 1 July 2018]

Bisley, N. (2013). 'An ally for all the years to come: why Australia is not a conflicted US ally', Australian Journal of

\footnotetext{
${ }^{72}$ Clarke \& X, Gao, op.cit, pp. 844
} 
51 Johni R. V. Korwa | The China-Australia Free Trade Agreement (ChAFTA): Its Implications for Australia-United States Relations

International Affairs, Vol. 67, No. 4, , pp. 403-418

Blumenthal, D., 'Strengthening the US-Australia Alliance: Progress and Pitfalls', 2005, American Enterprise Institute for Public Policy Research, Vol. 29, pp. 1-7

Brown, G and Rayner, L., 'Upside, Downside: ANZUS: After 50 years', 28 August 2001, Retrieved from http://www.aph.gov.au/About_Parliamen t/Parliamentary_Departments/Parliament ary_Library/Publications_Archive/CIB/ci b0102/02CIB03 [Accessed 5 June 2018]

Clarke, A dan Gao, X. (2007). 'Bilateral Free Trade Agreements: A comparative analysis of the Australia-United States FTA and the forthcoming AustraliaChina FTA', UNSW Law Journal, Vo. 30, No. 3, pp. 842-854

Clinton, H. (2011). America's Pacific Century', Foreign Policy, Issue. 189, pp. 56-63

Department of Foreign Affairs and Trade, 'Guiding to using ChAFTA to export or import', Retrieved from https://dfat.gov.au/trade/agreements/inforce/chafta/doing-business-withchina/Pages/guide-to-using-chafta-toexport-or-import.aspx [Accessed 1 July 2018]

Department of Foreign Affairs and Trade, 'ChAFTA snapshot infographic', Retrieved from http://dfat.gov.au/trade/agreements/inforce/chafta/fact-sheets/Pages/chaftasnapshot-infographic.aspx [Accessed 1 July 2018]
Department of Foreign Affairs and Trade, 'Australia's Trade and Economic Statistics', Retrieved from http://dfat.gov.au/aboutus/publications/trade-investment/trade-ata-glance/trade-at-a-glance2014/Pages/performance-03-australiastrade-and-economic-statistics.aspx [Accessed 3 June 2018]

Department of Foreign Affairs and Trade, 'China-Australia Free Trade Agreement', Retrieved from http://dfat.gov.au/trade/agreements/inforce/chafta/fact-sheets/Pages/fact-sheetresources-energy-andmanufacturing.aspx [Accessed 1 July 2018]

Department of Foreign Affairs and Trade, 'Joint Statement Australia-U.S. Ministerial Consultations (“AUSMIN")" 2018, Retrieved from https://foreignminister.gov.au/releases/Pa ges/2018/jb_mr_180724a.aspx [Accessed 6 June 2018]

Goldstein, A. (1893). An emerging China's emerging grand strategy', in G. J. Ikenberry \& M. Mastanduno (ed), International Relations Theory and the Asia-Pacific, New York: Columbia University Press.

Grieco, J, Ikenberry, G. J., and Mastanduno., M. (2015). Introduction to International Relations: enduring questions and contemporary perspectives, Great Britain: Palgrave.

He, B. (2014). 'Collaborative and Conflictive Trilateralism: Perspectives from Australia, China, and America', Asian Survey, Vol. 54, No.2, pp. 247-272 
52 Johni R. V. Korwa | The China-Australia Free Trade Agreement (ChAFTA): Its Implications for Australia-United States Relations

He, L. L., and Sappideen, R. (2013). 'Free trade agreements and the US-China-Australia relationship in the Asia-Pacific region', Asia Pacific Law Review, Vol. 21, No. 1, pp. 55-76

Kelton, M. (2008). More than an Ally? Contemporary Australia-US Relations, Ashgate Publishing Limited (England) \& Ashgate Publishing Company (USA),

Lee, J. (2013). 'Australia's 2015 Defense White Paper; Seeking Strategic Opportunity in Southeast Asia to Help Manage China's Peaceful Rise', Contemporary Southeast Asia, Vol. 35, No. 3, pp. 395-422

Lieberthal, K. (2005). 'Preventing a war over Taiwan', Foreign Affairs, Vol. 84 (2), pp. 1-6

Lum. T, Morrison, W. M., and Vaughn, B., (2008). 'China's "Soft Power" in Southeast Asia,' CRS report for Congress, pp. 1-21

Mearsheimer, J, J. (2001). The Tragedy of Great Power Politics, USA: W. Norton and Company.

Maersheimer, J. J. (2010). 'Structural Realism', in T. Dunne, M. Kurki and S. Smith (2nd edition), International Relations Theories: Discipline and Diversity, USA: Oxford University Press.

Report from the Joint Committee on Foreign Affairs and Defense, the ANZUS Alliance, Australian Government Publishing Service (Annex A - Security Treaty between Australia, New Zealand, and the United States of America), 1982.
The ANZUS Alliance. (1982). Australian Government Publishing Service, Canberra.

The 2016 Defence White Paper.

Retrieved from www.defence.gov.au/whitepaper/docs/20 16-defence-white-paper.pdf [Accessed 5 June 2018]

The North Atlantic Treaty (1949). Retrieved from http://www.nato.int/nato_static/assets/pdf /stock_publications/20120822_nato_treat y_en_light_2009.pdf [Accessed 21 May 2015]

The 2017 Foreign Policy White Paper (Australian Government). Retrieved from https://www.fpwhitepaper.gov.au/file/26 51/download?token=Q5CYuX29 [Accessed 6 June 2018]

Tom, W and L. Hay, L. (2001). 'Australia, the United States and a 'China growing strong': managing conflict avoidance', Australian Journal of International Affairs, Vol. 55, No. 1, pp. 37-54

Tow, S. R. (2011). 'Diplomacy in an asymmetric alliance: reconciling Sino-Australian relations with ANZUS, 1971-2007', International Relations of the AsiaPacific, Vol. 12, No. 1, pp. 71-100

Tow, W. T., and L. Hay, L. (2001) 'Australia, the United States and a 'China growing strong': managing conflict avoidance', Australian Journal of International Affairs, Vol. 55, No. 1, , pp. 37-54

U.S. Department of State, '2015 AustraliaUnited States Ministerial (AUSMIN) Joint Statement', Retrieved from 
53 Johni R. V. Korwa | The China-Australia Free Trade Agreement (ChAFTA): Its Implications for Australia-United States Relations

https://2009-

2017.state.gov/r/pa/prs/ps/2015/10/24817

0.htm [Accessed 6 June 2018]

Vaile, M., MP (former minister for trade),

'Australia-China Trade and Economic

Framework', 24 October 2003 Retrieved

from

http://trademinister.gov.au/releases/2003/

mvt085_03.html [Accessed 28 June

2018]

White, E. (Financial Times). 'Trump says he is

now opposed to re-joining TPP', 18 April

2018 Retrieved from

https://www.ft.com/content/ed6b16f4-

42b5-11e8-803a-295c97e6fd0b

[Accessed 28 June 2018]

White, H. (2011). 'Power shift: rethinking

Australia's place in the Asian century', Australian Journal of International

Affairs, Vol. 65, No. 1, ,pp. 81-93 